\title{
Editorial: Nature's Contributions to People: On the Relation Between Valuations and Actions
}

\author{
Thomas H. Beery ${ }^{1}$, Martin Quaas ${ }^{2}$ and Marie Stenseke ${ }^{3 *}$ \\ ${ }^{1}$ Faculty for Teacher Training, Man and Biosphere Health Research Group, Kristianstad University, Kristianstad, Sweden, \\ ${ }^{2}$ Biodiversity Economics Group, Department of Economics, German Centre for Integrative Biodiversity Research (iDiv), \\ Leipzig University, Leipzig, Germany, ${ }^{3}$ Unit for Human Geography, Department of Economy and Society, School of Business, \\ Economics and Law, University of Gothenburg, Göteborg, Sweden
}

Keywords: biodiversity, awareness, multiple values, practices, transformative changes

\section{Editorial on the Research Topic}

\section{Nature's Contributions to People: On the Relation Between Valuations and Actions}

How do the valuations of nature's contributions to people, i.e., all the benefits humanity obtains from nature, link to concrete actions?

In line with other bodies and a manifold of researchers addressing contemporary environmental challenges, the Global Assessment of Biodiversity and Ecosystem Services, published by the Intergovernmental Science-Policy Platform on Biodiversity and Ecosystem Services (IPBES), concludes that a fundamental reorganization across technological, economic, and social factors,

\section{OPEN ACCESS}

Edited and reviewed by: Orsolya Valkó,

Hungarian Academy of

Science, Hungary

*Correspondence:

Marie Stenseke

marie.stenseke@geography.gu.se

Specialty section:

This article was submitted to

Conservation and Restoration

Ecology,

a section of the journal

Frontiers in Ecology and Evolution

Received: 21 May 2021

Accepted: 02 June 2021

Published: 25 June 2021

Citation:

Beery TH, Quaas M and Stenseke M

(2021) Editorial: Nature's Contributions to People: On the Relation Between Valuations and Actions. Front. Ecol. Evol. 9:712902. doi: 10.3389/fevo.2021.712902 including values, is needed to achieve goals for conserving and sustainably using nature (IPBES, 2019). This reorganization implies transformative changes, for example, in the production and consumption of energy, food, and fiber.

While scientists and decision-makers increasingly acknowledge the need for transformative change, we lack specific definitions of the details of transformative change and agreement on how such change is ensured. However, by clarifying and assessing the multiple values of nature and its benefits, we understand what is at stake, for whom, and the tools for making priorities (Díaz et al., 2018, 2019). Valuation is, though, a means to an end. Likewise, increased awareness of the values of biodiversity is also a means to an end. The links between valuation, increasing awareness, and concrete actions, among policymakers and other decision-makers, including individuals, are crucial for transformative changes to start and proceed.

These considerations reverse the established approach in economic valuation, according to which one uses observations about actual actions to infer the values the actor holds ("revealed preferences"). In line with this economic paradigm, the currently observed societal actions and resulting biodiversity change reveals a lack of societal valuation of nature's contributions to people. If we would "transform our world," as the UN's Agenda 2030 demands, and with it the way societies act toward nature, this would reveal a new social valuation of nature's contributions to people. Either way, there is a close relationship between actions and valuations.

The articles in this Research Topic present insights from various perspectives and theoretical and methodological approaches on the connections between valuations of nature's contributions to people, including ecosystem services, awareness, and concrete actions. The articles concern perceptions and actions among individuals and groups of people and aspects related to governance ranging from local to global scales, based on cases from various parts of the world.

Some of the articles highlight how we understand "value" and the plurality of ways in which 
people value the rest of nature and discuss the implications for governing. Beery and Lekies consider children's nature experiences and highlight how child relationship to nature demonstrates relational value; Beery and Lekies argue that children's perspectives need to be better considered in ecosystem valuation and decision making. Johansson et al. elaborate on the understandings of "value." Using the case of humanwildlife encounters, they propose a psychological framework for understanding positive and negative contributions of wildlife for peoples' nature experiences, having a specific focus on their restorative effects.

Leventon et al. discuss the need for transforming biodiversity governance systems, departing from Donella Meadows' leverage points. They argue that plural valuation of biodiversity requires engagement with deep leverage points for governance system transformation, i.e., the intent and goals of the system, and not just the design of it.

Bravo-Monroy explores nature's contributions to people using Lefebvre's social theory as an analytical tool. Bravo-Monroy looks into the various meanings of place in coffee and potato farmer communities in Colombia and describes three co-existing spaces: lived spaces, perceived spaces, and conceived spaces. Bravo-Monroy points at the potential to facilitate communication on land use by recognizing nature's contributions to people with the help of those dimensions.

A couple of articles explore the links between values and behavior. Salazar et al. review tools that assess people's connections to nature, with a specific aim to identify tools helpful to managers and practitioners. Maioli et al. present a study of local stakeholders' perceptions and their relation to their local environment in the Brazilian Atlantic Forest. Maioli et al. illustrate the usefulness of this kind of insight for designing more effective landscape management and planning strategies.

Hysing and Lidskog and Stålhammar take a conceptual turn and address the role of concepts and concept innovation. Hysing and Lidskog delve into the issue of ecosystem services vs. nature's contributions to people, asking if conceptual innovation can

\section{REFERENCES}

Albrechts, L., Barbanente, A., and Monno, V. (2020). Practicing transformative planning: the territory-landscape plan as a catalyst for change. City Territory Architect. 7, 1-13. doi: 10.1186/s40410-019-0111-2

Díaz, S., Pascual, U., Stenseke, M., Martín-López, B., Watson, R. T., Molnár, Z., et al. (2018). Assessing nature's contributions to people. Science 359, 270-272. doi: 10.1126/science.aap8826

Díaz, S., Settele, J., Brondízio, E. S., Ngo, H. T., Agard, J., Arneth, A., et al. (2019). Pervasive human-driven decline of life on Earth points to the need for transformative change. Science 366:eaax3100. doi: 10.1126/science.aax 3100

IPBES (2019). Global Assessment of Biodiversity and Ecosystem Services Global Assessment of Biodiversity and Ecosystem of the Intergovernmental SciencePolicy Platform on Biodiversity and Ecosystem Services (IPBES). Bonn. generate transformative change. Taking the use of ecosystem services among policy practitioners in Sweden as a case, they point at the necessity to pay attention to interpretative frames and give a strong role to social analysis in the process of conceptual innovation. Stålhammar looks into the link between values and sustainability transformations. Stålhammar highlights the distinction between descriptive and normative modes of values and argues that the latter mode needs to be better recognized. Faith takes the perspective of intergenerational justice and highlights the value of "maintenance of options," one of the 18 categories of "nature's contributions to people" defined by IPBES, and underlines the importance of considering this futurelooking aspect.

The mix of valuation and action insights included in the articles of this Research Topic is in line with calls for novel, positive, and engaging visions of the future. Transformation will require a coordinated and inclusive understanding of transformative change toward greater uptake of biodiversity and ecosystem services and mobilizing a broad base of local actors (e.g., Albrechts et al., 2020). The ideas and visions included in this collection represent the need for a rich diversity of functions and understandings of values. Altogether, the articles demonstrate that this diversity must include theory, policy, and case studies, from guiding ideas to guiding practice. Ultimately, to achieve the transformative change that UN Agenda 2030 calls for, scientists, planners, and natural resource managers will need to work with the help of the creative professions (e.g., artists and philosophers) and the service professions (e.g., education, medical care, elder care, and childcare). Such collaboration must strive to recognize and integrate diverse worldviews and knowledge systems (Parsons and Fisher, 2020).

\section{AUTHOR CONTRIBUTIONS}

All authors listed have made a substantial, direct and intellectual contribution to the work, and approved it for publication.

Parsons, M., and Fisher, K. (2020). Indigenous peoples and transformations in freshwater governance and management. Curr. Opin. Environ. Sustain. 44, 124-139. doi: 10.1016/j.cosust.2020.03.006

Conflict of Interest: The authors declare that the research was conducted in the absence of any commercial or financial relationships that could be construed as a potential conflict of interest.

Copyright (c) 2021 Beery, Quaas and Stenseke. This is an open-access article distributed under the terms of the Creative Commons Attribution License (CC BY). The use, distribution or reproduction in other forums is permitted, provided the original author(s) and the copyright owner(s) are credited and that the original publication in this journal is cited, in accordance with accepted academic practice. No use, distribution or reproduction is permitted which does not comply with these terms. 